\title{
空調システムの運用における熱源インバー夕制御の省エネルギー効果 EFFECTS ON ENERGY CONSERVATION BY INVERTER CONTROLS OF HEAT SOURCE EQUIPMENT IN BUILDING AIR-CONDITIONING SYSTEM OPERATIONS
}

\author{
住吉大輔*1, 赤司 泰義*2, 渡辺俊行*3 \\ 神村一 幸*4, 西山紀光*5, 崔軍*6 \\ Daisuke SUMIYOSHI, Yasunori AKASHI, Toshiyuki WATANABE, \\ Kazuyuki KAMIMURA, Norimitsu NISHIYAMA and Jun CUI
}

\begin{abstract}
This paper presents an energy performance analysis of an air-conditioning system with heat pump chillers controlled by inverters. The inverter is attached to the chiller's compressor, and controls the number of revolutions of the motor. As a result, the efficiency of the chiller in a partial load can be largely improved more than in a full load. Traditionally, a chiller in a HVAC\&R system is operated at a full load from the viewpoints of the energy much. However, if an inverter is attached to the chiller, there is a possibility that the chiller's partial load operation will make the energy efficiency higher. This inverter utilization is one effective solution to reduce the energy consumption. The energy performance is evaluated by the HVAC\&R's measurements and a simulation analysis.
\end{abstract}

\section{Keywords : Inverter, Part-load Operation, Heat Pump, Energy Conservation, Numerical Simulation} インバータ、部分負荷運転、ヒートポンプ、省エネルギー、数值シミュレーション

1 はじめに

これまでの建築空調分野における省エネルギーは、「建物計画に よる空調負荷の低減」もしくは「適切な空調システムの採用と設 計」に重点がおかれていた。省エネルギーの推進には、これらに加 えて「空調システムの適切な運用」が不可欠である。

空調分野の般送系を担っているポンプやファンについては、部分 負荷運転時の効率が良いインバータ制御が開発・導入され、インバ 一タの価格低下に伴う普及促進によって大きな省エネルギー効果 をあげてきた。また、最近では地域冷暖房施設等で用いる大型の熱 源機器や個別分散型空調システム(ビルマルチ)にインバータが導入 され、省エネルギーが図られており、既往の研究にもそうしたもの が数多く見られる例えは1 1),2)。しかしその一方で、ビル用空調方式の主 流の一つである中央供給方式で用いられるヒートポンプチラーに、 インバータ制御の導入を行う研究はほとんど見当たらない。ヒート ポンプチラー等の熱源機器の装置容量は空調負荷のピーク值にあ わせて選定されるので、年間を通じてほんのわずかなピーク時以外 は、ほとんどが部分負荷運転となっている。運転効率が低下する部 分負荷運転を避け、できるだけ全負荷運転を可能にするため、現在 は、要求される装置容量を分割して複数台の熱源機器を用意する等 の対応がとられている。しかしながら、部分負荷運転時の効率が全 負荷運転時より向上するインバータ制御をヒートポンプチラーに 導入することができれば、中央供給方式の空調システムでも大きな 省エネルギー効果を生み出す可能性がある。

本研究では、ヒートポンプチラーにインバータを導入する熱源イ ンバータ制御を開発し、それを用いたより省エネルギーな運用方策
とその効果を実験・実測・空調システムシミュレーションにより明 らかにすることを目的としている。熱源インバータ制御は既存の空 調システムに導入可能な手法であるため、システムの改修時に導入 することを想定し、実験・実測はビル空調で用いられる汎用の熱源 機器の圧縮機部分にインバータを取り付けて行った。

\section{2 熱源インバータ制御}

2.1 インバータ制御の省エネルギー効果と熱源機器への適用3),4) 循環ポンプのように高低差による圧力損失がほとんど無いポン プの回転速度をインバータによってある範囲内で変化させる場合 には、流量、軸動力に理論上次の関係が成立する。

$$
\begin{aligned}
& \frac{Q}{Q_{0}}=\frac{N}{N_{0}} \\
& \frac{P}{P_{0}}=\left(\frac{N}{N_{0}}\right)^{3}
\end{aligned}
$$

ここで、 $N$ : 運転時の回転速度 $\left[\mathrm{min}^{-1}\right] 、 N_{0}$ : 定格回転速度 [min'-1]、 $Q: N$ のときの流量 $\left[\mathrm{m}^{3} / \mathrm{h}\right] 、 Q_{0}:$ 定格流量 $\left[\mathrm{m}^{3} / \mathrm{h}\right]$ 、 $P: N$ のときの軸動力 $[\mathrm{kW}] 、 P_{0}:$ 定格時の軸動力 $[\mathrm{kW}]$

したがって、軸動力は流量の3乗に比例し、例えば流量が $80 \%$ に なれば軸動力は理論上 $51 \%$ に減少するため、大幅に電力消費量を削 減できる。一方、高低差による圧力損失が存在する揚水ポンプ等で は動力と流量の関係は図1の様になり、高低差による圧力損失(実揚 程)が大きいほど効率が低下する。しかしながらバルブ制御に比べイ ンバータ制御では部分負荷運転時に高効率な運転が可能である。

ヒートポンプについて考えてみると、冷媒回路中には寒揚程に相
*1 九州大学大学院人間環境学府 院生 - 修士 (工学)

*2 九州大学大学院人間環境学研究院 助教授. 博士 (工学)

*3 九州大学大学院人間環境学研究院 教授. 工博

*4 怢山武ビルシステムカンパニ一研究開発部

担当部長・博士 (工学)

*5 久留米工業大学工学部建築 ·設備工学科 教授 ·博士 (工学)

${ }^{* 6}$ 近畿大学工学部建築学科 助教授 $\cdot$ 博士 (工学:
Student, Graduate School of Human-Environment Studies, Kyushu Univ., M. Eng. Assoc. Prof., Faculty of Human-Environment Studies, Kyushu Univ., Dr. Eng. Prof., Faculty of Human-Environment Studies, Kyushu Univ., Dr. Eng.

Director, Research and Development Department, Building Systems Company, Yamatake Co., Dr. Eng.

Prof., Dept. of Architecture and Building Services Engineering, Kurume Institute of Technology, Dr. Eng.

Assoc. Prof., Dept. of Architecture, Kinki Univ., Dr. Eng. 
当する冷媒流量に無関係な圧力損失が存在し、さらに電動機や圧縮 機等の摩擦による動力損失もある。そのため、インバー夕制御によ る熱源機器の動力特性は実揚程が存在する揚水ポンプの動力特性 に近い傾向を示すことが予想され、インバータ制御を用いずに運転 を行う場合に比べ高効率な運転が期待できる。

\section{2 熱源インバータ制御特性把握実験}

インバータ制御の熱源機器への導入は様々なメリットを生むと 推察されるが、前節で示した様に機器内部での圧損失等の影響に より機種によって特性に差が出ることが考えられる。また、出力を 下げすぎると熱源機器内の冷媒が循環しなくなり、機器に悪影響を 与える危険性もある。そこで、熱源機器にインバータ制御を導入し た場合にどのような挙動を示すか、また、生産熱流量と消費電力の 間にどのような関係があるかを明らかにするため、仕様の異なる 2 台の熱源機器について寒験を行った。実験では、1 次ポンプのイン バータ制御特性も測定した。対象機器の仕様を表 1 に示す。

\section{（1）熱源機器実験概要}

熱源機器のインバー夕周波数を変化させ、操作後 10 分経過した 後に熱源機器周囲の外気温度、冷温水流量、熱源冷温水出入口温度、

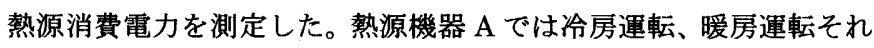
ぞれについて実験を行い、インバー夕周波数を $50 \mathrm{~Hz}$ から $15 \mathrm{~Hz}$ ま で $5 \mathrm{~Hz}$ 刻みで变化させて測定した。熱源機器 $\mathrm{B}$ では冷房運転を行 い $50 \mathrm{~Hz}$ から $25 \mathrm{~Hz}$ の範囲について測定を行った。対象機器は定格 周波数が $50 \mathrm{~Hz}$ の地域にあるため $50 \mathrm{~Hz}$ 以下の範囲について測定し ている。測定時には 1 次ポンプを全負荷運転した。

\section{(2) 1 次ポンプ実験概要}

1 次ポンプのインバータ制御特性把握実験を行った空調システム は配管経路を弁により切り替えることで、蓄熱と非蓄熱の各運転方 法で運転を行うことができるシステムである。空調システム系統略 図を図 2 に示す。蓄熱空調システムでは、夜間の蓄熱運転、昼間の 追いかけ運転ともに熱源機器で生成した冷温水を 1 次ポンプで蓄熱 槽に送る。放熱は熱交換器を通して行う。非蓄熱空調システムでは、 熱源機器で生成した冷温水を 1 次ポンプにより直接 2 次側へ送る。 実験では蓄熱空調システムと非蓄熱空調システムのそれぞれにつ いて 1 次ポンプのインバータ制御特性を測定した。測定したインバ 一タ周波数の範囲は $50 \mathrm{~Hz} \sim 35 \mathrm{~Hz}$ である。1 次ポンプのインバータ 周波数を変化させ、10 分経過した後に流量と消費電力を測定した。 (3) 実験結果 ·考察

実験結果を用いて表 2、3 に示寸式により部分負荷率および電力 消費率を算出し、プロットしたものが図 $3 、 4$ である。熱源機器の 効率は外気温度と熱源冷温水出入口温度に左右され変化するが、そ の変化割合を表わしたものが能力比や入力比である。能力比・入力

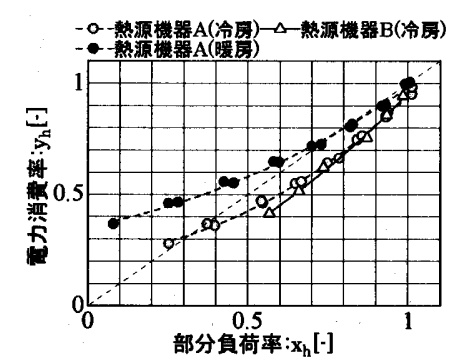

図 3 熱源インバータ制御特性

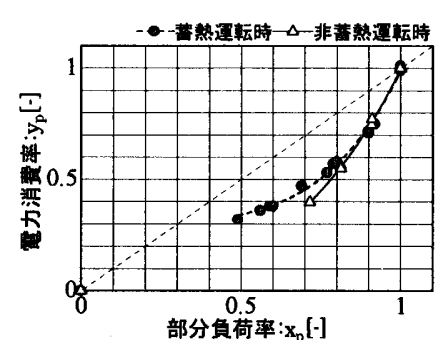

図 41 次ポンプインパータ制御特性

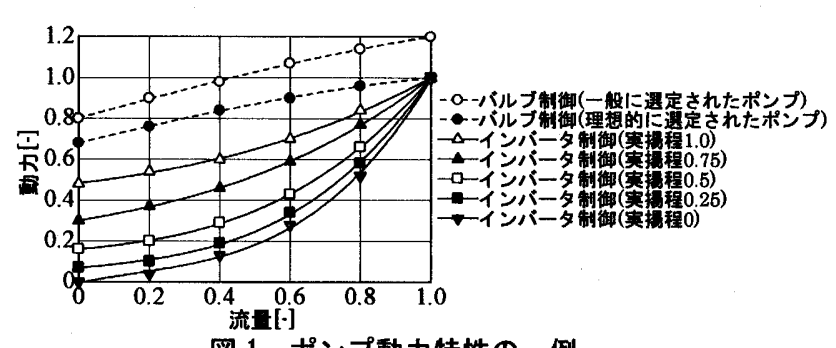

図 1 ポンプ動力特性の一例

\section{表 1 実験対象機器の仕様}

\begin{tabular}{|c|c|}
\hline & 機器仕様 \\
\hline 熱源機器 A & $\begin{array}{l}\text { 形式: 空冷ヒートポンプチラー (全密閉スクロール式) } \\
\text { 定格能力(椧却) }: 58.6 \mathrm{~kW} \text {, 定格能力(加熱) }: 67.0 \mathrm{~kW} \\
\text { 冷温水流量 : } 7.2 \mathrm{~m}^{3} / \mathrm{h} \text {, 定格消費電力 }: 23.7 \mathrm{~kW} \text {, 圧縮 } \\
\text { 機用電動機出力 }: 7.5 \mathrm{~kW} \times 2 \text { 台 }+3.75 \mathrm{~kW} \times 2 \text { 台 } \\
\text { ※インバータ } \mathrm{A} \times 2 \text { 台、インバータ } \mathrm{B} \times 2 \text { 台を設置 }\end{array}$ \\
\hline 熱源機器 B & $\begin{array}{l}\text { 形式: 空冷ヒートポンプチラー（全密閉レシプロ式） } \\
\text { 定格能力(椧却) }: 46.7 \mathrm{~kW} \text {, 定格能力(加熱) }: 41.2 \mathrm{~kW} \\
\text { 冷温水流量 }: 7.98 \mathrm{~m}^{3} / \mathrm{h} \text {, 定格消費電力 }: 17.1 \mathrm{~kW} \text {, 压縮 } \\
\text { 機用電動機出力 }: 7.5 \mathrm{~kW} \times 2 \text { 台 } \\
\text { ※インバータ } \mathrm{B} \times 2 \text { 台を設置 }\end{array}$ \\
\hline 1 次ポンプ & $\begin{array}{l}\text { 定格流量 : } 7.2 \mathrm{~m}^{3} / \mathrm{h}, \text { 定格消費電力 }: 1.5 \mathrm{~kW} \\
\text { ※インバータ } \mathrm{C} \times 1 \text { 台を設置 }\end{array}$ \\
\hline $\begin{array}{c}\text { インバータ } \\
\mathbf{A}\end{array}$ & $\begin{array}{l}\text { 適用モータ容量 : } 5.5 \mathrm{~kW} \text {, 定格容量 : } 8.8 \mathrm{kVA} \text {, 定格電 } \\
\text { 流 : } 23 \mathrm{~A} \text {, 定格入力: 交流 } 3 \text { 相 } 200 \mathrm{~V} 50 \mathrm{~Hz}\end{array}$ \\
\hline $\begin{array}{c}\text { インバータ } \\
\mathrm{B}\end{array}$ & $\begin{array}{l}\text { 適用モータ容量 : } 7.5 \mathrm{~kW} \text {, 定格容量: } 11.8 \mathrm{kVA} \text {, 定格 } \\
\text { 電流 : } 31 \mathrm{~A} \text {, 定格入力 : 交流 } 3 \text { 相 } 200 \mathrm{~V} 50 \mathrm{~Hz}\end{array}$ \\
\hline $\begin{array}{l}\text { インバータ } \\
\mathrm{C}\end{array}$ & $\begin{array}{l}\text { 適用毛一夕容量 : } 1.5 \mathrm{~kW}, \text { 定格容量 : } 2.7 \mathrm{kVA} \text {, 定格電 } \\
\text { 流 : } 7.1 \mathrm{~A} \text {, 定格入力 : 交流 } 3 \text { 相 } 200 \mathrm{~V} 50 \mathrm{~Hz}\end{array}$ \\
\hline
\end{tabular}

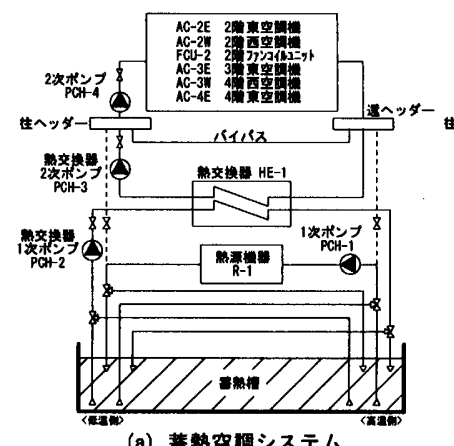

(a) 著熱空誦システム

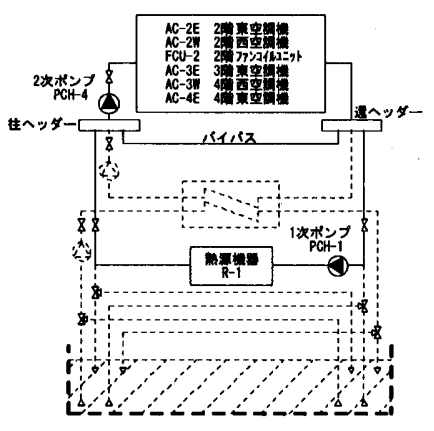

(b) 非蓄薢空湅システム

図 2 空調システム系統略図

表 2 熱源機器の指權算出式
$x_{h}=\frac{q}{O}=\frac{q}{Q \times R_{O}}$
（式 3）
$y_{h}=\frac{e_{h}}{I}=\frac{e_{h}}{E_{h} \times R_{I}}$
(式 4)

ここで、 $x_{h}$ :部分負荷率[-]、 $q$ :生産熱流量[kW]、 $O$ :最大能力 $[\mathrm{kW}]$,

$Q$ : 定格能力 $[\mathrm{kW}] 、 R_{O}$ :能力比 $[-] 、 y_{h}$ :電力消费率 $[-] 、 e_{h}$ 消費電力 $[\mathrm{kW}] 、 I$ :最大入力 $[\mathrm{kW}] 、 E_{h}$ : 定格消費電力 $[\mathrm{kW}] 、 R_{I}$ :入力比[-]

表 31 次ポンプの指標算出式
$x_{p}=\frac{\mathrm{W}}{\mathrm{W}}$
(式 5)
$y_{p}=\frac{e_{p}}{\mathrm{E}_{\mathrm{p}}}$
(式 6)
ここで、 $x_{p}$ : 部分負荷率[-]、w: 流量 $\left[\mathrm{m}^{3} / \mathrm{h}\right] 、 W$ : 定格流量 $\left[\mathrm{m}^{3} / \mathrm{h}\right]$ 、 $y_{p}$ : 電力消費率 $[-] 、 e_{p}$ : 消費電力 $\left[\mathrm{kW} 、 E_{p}\right.$ : 定格消费電力 $[\mathrm{kW}]$

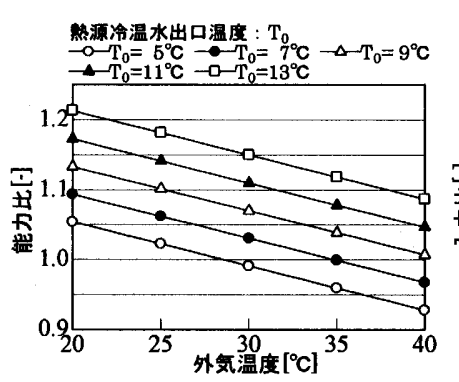

(a) 能力比

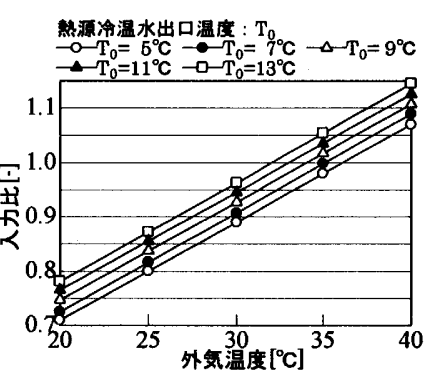

(b) 入力比
図 5 能力比・入力比(熱源機器 A、冷房時) 
比には、測定時の外気温度、熱源冷温水出口湿度を用いて機器の仕 様書より求めた值を使用した。例として熱源機器Aにおける冷房時 の能力比・入力比を図5に示す。例えば外気温度が $20^{\circ} \mathrm{C}$ 、熱源冷温

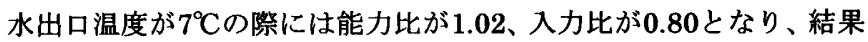
全負荷運転時(部分負荷率・電力消費率ともに1.0)には生産熱流量が 定格能力の 1.02 倍、消費電力が定格消費電力の 0.8 倍となる。そのた め、熱源機器の成績保数(熱源COP)は1.28倍に向上する。生産熱流 量は熱源冷温水出入口温度差と冷温水流量、比熱から求めている。 熱源機器・1次ポンプともに定格能力(定格流量)と定格消費電力には、 機器仕様書に記載されている值(表1)ではなく、周波数制御を行って いない従来通りの運転時（部分負荷率1.0）に測定した值を使用した (表4)。ただし熱源機器の定格値には、外気温度と熱源冷温水出口温 度の影響を補正するために生産熱流量(消費電力)の測定値を能力比 (入力比)で除した値を使用した。表5には実駼結果より最小二乗法を 用いて算出したインバータ制御特性式をまとめる。式中の $\mathrm{x}_{\mathrm{h}}\left(\mathrm{x}_{\mathrm{p}}\right)$ が 部分負荷率、 $\mathrm{y}_{\mathrm{h}}\left(\mathrm{y}_{\mathrm{p}}\right)$ が電力消費率である。実験では、インバータを用 いても熱源機器に当初懸念されたような不具合を生じることなく運 転できた主1)。冷房運転時には、部分負荷運転時において全負荷運転 時よりも効率の良い熱量生産が可能であることが明らかになった。 また、2台の熱源機器のインバータ制御冷房運転における特性には 違いが見られた。この要因として実験時の外気温度等の条件が異な ることも挙げられるが、能力比・入力比による補正を行った上で特 性を算出しており、圧縮機の仕組みやモーターサイズ等の影響によ り熱源機器内部の圧力損失や動力損失の個体差が大きいものと考え られる。一方で暖房運転時には期待された効率の向上がほとんど見 られなかった。その要因として暖房運転時には冷房運転時に比べ熱 源機器内の冷媒と外気温度との温度差が大きく、冷媒の流速が低下 するインバータ制御では熱損失が大きくなること、低部分負荷時に おける機器発熱の減少が冷房時ではプラスに作用するが暖房時には マイナスに作用すること等が考えられる。

\section{3 実測調查}

前節の実験により、熱源インバータ制御は冷房運転時に高効率な 運転を実現できることが明らかになった。このことは、蓄熱温度(熱 源冷水出口温度)や2次側送水温度・圧力等の設定值を常にある一定 の値とする従来の空調システムの運用方策に対して、積極的に熱源 機器を部分負荷で運転することによって、熱源機器の成績係数(熱源 COP)向上を図り、省エネルギーを実現できる可能性を示している。 そこで、実測では送水温度の変更、1次ポンプ変流量運転、熱源イ ンバータ制御を組み合わせた運用を行い、どの程度の省エネルギー

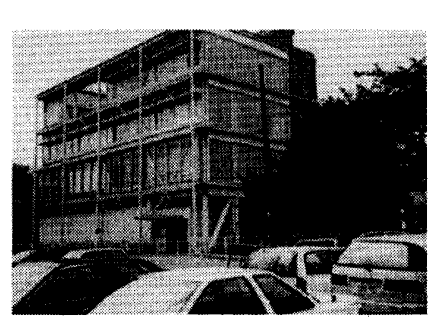

写真 1 実測対象建物外観

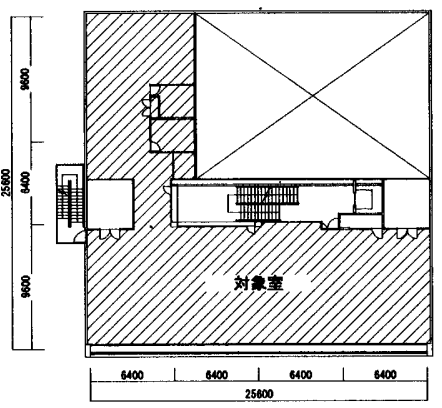

(a) 2 階平面图
効果が得られるのか調查した。調查期間は2002年10月14日から 25 日であり、期間中は冷房運転を行った。蓄熱空調システムでの調查 を14日から18日に、非蓄熱空調システムでの調查を21日から25日に 行った。空調時間帯は概ね8時30分から18時30分である。対象とし た施設で常時 1 分間隔で計測されているデータに加え、熱源機器周 辺の外気温度を 1 分間隔で測定し、熱源機器と 1 次ポンプの消費電力 を2分間隔で測定した。

\section{1 対象建物・空調システム概要}

実測を行った空調システムは、前章に記した熱源インバータ制御 特性把握実験で、熱源機器Aならびに1次ポンプの実験を行ったシス テムである(図2)。表6に建物概要、写真1に建物外観、図6に各階平 面図、表7に空調設備概要を示す。

表 4 実測値より算出した機器定格值

\begin{tabular}{|c|c|c|c|c|}
\hline \multirow{2}{*}{ 熱源機器 A } & 冷房運転 & \multicolumn{3}{|c|}{ 定格能力: $62.07 \mathrm{~kW}$ ，定格消費電力：26.85kW } \\
\hline & 暖房運転 & \multicolumn{3}{|c|}{ 定格能力: $76.68 \mathrm{~kW}$, 定格消費電力: $24.81 \mathrm{~kW}$} \\
\hline 熱源機器 B & 冷房運転 & \multicolumn{3}{|c|}{ 定格能力: 42.61kW，定格消費電， $: 20.76 \mathrm{~kW}$} \\
\hline \multirow{2}{*}{1 次ポンプ } & 蓄熱 & \multicolumn{3}{|c|}{ 定格流量 $: 7.86 \mathrm{~m}^{3} / \mathrm{h}$ ，定格消費電力: $1.78 \mathrm{~kW}$} \\
\hline & 非蓄熱 & \multicolumn{3}{|c|}{ 定格流量 : $5.60 \mathrm{~m}^{3} / \mathrm{h}$, 定格消費電力: $1.57 \mathrm{~kW}$} \\
\hline \multicolumn{5}{|c|}{ 表 5} \\
\hline \multicolumn{2}{|c|}{$\begin{array}{l}\text { 秷源機器 } \mathbf{A} \\
\end{array}$} & 熱源機器 B & \multicolumn{2}{|c|}{1 次ポンプ } \\
\hline 冷房運転時 & 暖裳運転時 & 冷房運転時 & 蓄熱運転時 & 非蓄熱運転時 \\
\hline$y_{h}=\sum a_{n} x_{h}^{n}$ & $y_{h}=\sum b_{n} x_{h}{ }^{n}$ & $y_{h}=\sum c_{n} x_{h}{ }^{n}$ & $y_{p}=\Sigma d_{n} x_{p}^{n}$ & $y_{p}=\sum e_{n} x_{p}^{n}$ \\
\hline$a_{0}=0.238$ & $b_{0}=0.3571$ & $c_{0}=0.0373$ & $\mathrm{~d}_{0}=0.8916$ & $e_{0}=0.7869$ \\
\hline$a_{1}=0.0476$ & $b_{1}=0.2695$ & $c_{1}=0.3544$ & $\mathrm{~d}_{1}=-2.2737$ & $e_{1}=-2.4329$ \\
\hline$a_{2}=0.6581$ & $\mathrm{~b}_{2}=0.3555$ & $c_{2}=0.5641$ & $\mathrm{~d}_{2}=2.3567$ & $e_{2}=2.6457$ \\
\hline
\end{tabular}

表 6 建物概要

\begin{tabular}{l|l}
\hline 所在地 & 東京都大田区 \\
\hline 主要用途 & オフィス・実験施設 \\
\hline 樓造・階数 & 鉄骨造・地上 4 階 \\
\hline 敷地面樻 & $4353.7 \mathrm{~m}^{2}$ \\
\hline 建築面積 & $703.97 \mathrm{~m}^{2}$ \\
\hline 延べ床面積 & $1697.05 \mathrm{~m}^{2}$ (対象床面積 $\left.: 741.76 \mathrm{~m}^{2}\right)$ \\
\hline
\end{tabular}

表 7 空調設備概要

\begin{tabular}{|c|c|c|}
\hline 名称/記号 & & 機器仕梯 \\
\hline $\begin{array}{l}2 \text { 階東空気請和味機/AC-2E } \\
2 \text { 階西空気調和機/AC-2W }\end{array}$ & 各1台 & $\begin{array}{l}\text { 冷去能力: } 33.72 \mathrm{~kW} \text {, 加熱能力: } 20.92 \mathrm{~kW} \text {, 泠水流量 : } \\
4.14 \mathrm{~m}^{3} \mathrm{~h} \text {, 温水流量 }: 2.58 \mathrm{~m}^{3} \mathrm{~h} \text {, 送風量 : } 6000 \mathrm{~m}^{3 / \mathrm{h}} \text {, } \\
\text { 消費電力 }: 5.9 \mathrm{~kW}\end{array}$ \\
\hline 2 階了/ב敒工外/FCU-2 & 1 台 & $\begin{array}{l}\text { 冷却能力 : } 4.5 \mathrm{~kW} \text {, 加熱能力: } 3.81 \mathrm{~kW} \text {, 冷水流量: } \\
0.54 \mathrm{~m}^{3 /} \mathrm{h} \text {, 温水流量 }: 0.48 \mathrm{~m}^{3} \mathrm{~h} \text { 送風量 : } 1000 \mathrm{~m}^{3 / \mathrm{h}} \text {, } \\
\text { 消費電力 }: 0.4 \mathrm{~kW}\end{array}$ \\
\hline 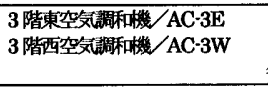 & 各1台 & $\begin{array}{l}\text { 冷却能力: } 31.39 \mathrm{~kW} \text {, 加熱能力: } 20.93 \mathrm{~kW} \text {, 冷水流量: } \\
3.84 \mathrm{~m}^{3} \mathrm{~h} \text {, 温水流量 }: 2.58 \mathrm{~m}^{3 /} \mathrm{h} \text {, 送風量 : } 400 \mathrm{~m}^{3} \mathrm{~h} \text {, } \\
\text { 消費電力 }: 3.7 \mathrm{~kW}\end{array}$ \\
\hline 4 階空気調和機 $/ \mathrm{AC}-4 \mathrm{E}$ & 1台 & $\begin{array}{l}\text { 椧却能力: } 36.04 \mathrm{~kW} \text {, 加熱能力: } 29.88 \mathrm{~kW} \text {, 冷水流量 : } \\
6.20 \mathrm{~m}^{3} \mathrm{~h} \text {, 晹水流量 : } 5.14 \mathrm{~m}^{3} / \mathrm{h} \text {, 送風量 : } 6000 \mathrm{~m}^{3 / 3} \text {, } \\
\text { 消費電力 : } 5.2 \mathrm{~kW}\end{array}$ \\
\hline 空给ヒートポンフチラー /R-1 & 1台 & $\begin{array}{l}\text { 椧去却能力: } 58.6 \mathrm{~kW} \text {, 加熱能力: } 67.0 \mathrm{~kW} \text {, 冷温水流量 : } \\
7.2 \mathrm{~m} 3 \mathrm{~h} \text {, 定格消費電力: } 23.7 \mathrm{~kW}\end{array}$ \\
\hline 1次ポンプ/PCH-1 & 1台 & 流量 : $7.2 \mathrm{~m}^{3} \mathrm{~h} \times 25 \mathrm{mAq}$, 消費電力 $: 1.5 \mathrm{~kW}$ \\
\hline 熱交喚器1次ポンナ/PCH-2 & 1台 & 流量: $13.2 \mathrm{~m}^{3} \mathrm{~h} \times 14 \mathrm{mAq}$, 消霓電力: $1.5 \mathrm{~kW}$ \\
\hline 熱交換器2次ポンプ/PCH-3 & 1台 & 流量 : $13.2 \mathrm{~m}^{3} \mathrm{~h} \times 12 \mathrm{mAq}$, 消費電力: $1.5 \mathrm{~kW}$ \\
\hline 2次ホホンプ/PCH-4 & 1台 & 流量 : $13.2 \mathrm{~m}^{3} / \mathrm{h} \times 18 \mathrm{mAq}$, 消債電力: $2.2 \mathrm{~kW}$ \\
\hline
\end{tabular}

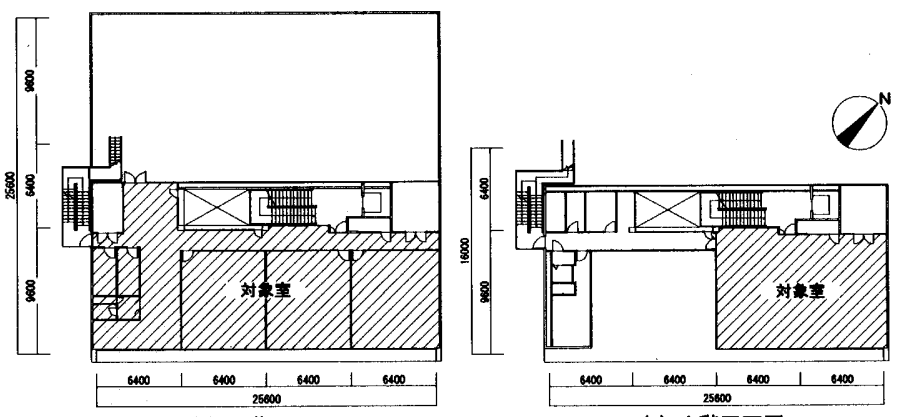

(b) 3 陵平面圆

(c) 4 階平面図

図 6 各階平面図（単位 : mm) 
東京都大田区に位置するオフィス兼実験施設であり、2、3階の事務 室、及び4階の会議室を対象室とした。他室は主に実験施設であり、 対象室の空調システムとは独立している。対象となる2階事務室、3 階事務室、4階会議室の空調システムは、熱源機器として空冷ヒ一 トポンプチラー1台(R-1)を用いており、温度成層型蓄熱槽(9槽、 $\left.74.67 \mathrm{~m}^{3}\right)$ を有する。2階には東西の空調機械室に各 1 台の空調機 (AC-2E、AC-2W) があり、定風量方式によって事務室の空調を行っ ている。事務室の北西部にはファンコイルユニット(FCU-2)があり、 補助的な空調を行っている。3階にも2階と同様に東西の空調機械室 に各1台の空調機(AC-3E、AC-3W)が配置され、VAVニニットによる 変風量方式で事務室の空調を行っている。4階の東側にある空調機 械室には、空調機1台(AC-4E)が配置されている。

\section{2 蓄熱空調システムにおける実測調查}

(1) 実測概要

夜間蓄熱時間帯は 22 時から翌8時までとした。実測では、従来の 運用方法で運転を行う case $\alpha-1$ と熱源機器・1次ポンプでの効率向上 を図れるよう設定したcase $\alpha-2$ とを実施し、比較した。両ケースの 設定条件を表8に示す。

〈case $\alpha-1\rangle(14$ 日 22:00 16日 17:00)

従来から対象空調システムで行われている運用で、熱源機器(R-1)、 1次ポンプ(PCH・1)は共に全負荷運転を行う。三方弁熱源出口温度、 蓄熱基準温度、熱交換器 2 次側送水温度、熱交換器 2 次側還水温度等 の設定值には従来対象空調システムで使用されている値を用いる。 〈case $\alpha-2\rangle(16$ 日 22:00 18日 18:00)

蓄熱空調システムでは、負荷に追従して熱源機器を稼動する必要 がないため、熱源機器の部分負荷運転が必要な状況は発生せず、こ れまでは最も効率が良い全負荷運転が行われてきた。しかし、熱源 インバータ制御を用いた場合には全負荷運転時よりもさらに効率の 良い運転が可能なため、蓄熱空調システムでは最も効率の良い部分 負荷率で運転するのが効果的である。また、通常1次ポンプは熱源 冷水出口温度の低下による凍結防止のため全負荷運転を行うが、熱 源機器を部分負荷運転とした場合には1次ポンプの流量を熱源機器 の部分負荷率に合わせて絞ることで、熱源冷水出口温度を低下させ ることなく安全に1次ポンプの電力消費量も削堿することができる。 そこで、前章の実験で得た特性式(表5)より熱源機器と 1 次ポンプを 同じ部分負荷率で運転した場合の1次側 $\mathrm{COP}($ 式7)が最高となる点 (以下、最高効率点)を求めた(図7)。最高効率点は両機器の部分負荷 率が0.6の時であった。case $\alpha$-2では蓄熱運転、追いかけ運転をする 際に熱源機器、1次ポンプともインバータ制御により最高効率点で 運転する。また、熱源機器は熱源冷水出口温度が高いほど高効率と なる。熱源機器が高効率で運転できればその相乗効果として、イン バータ使用時に部分負荷率がより低くなり効率向上も期待できる。 そこでcase $\alpha-2$ では熱源冷水出口温度を $2 \mathrm{~K}$ 上昇させるため、関係す る各設定值(三方弁熱源出口温度、蓄熱基準温度、熱交換器 2 次側送 水温度、熱交換器 2 次側還水温度)をcase $\alpha-1$ から $2 \mathrm{~K}$ 上げて運転する。

$$
\operatorname{COP}_{p}=\frac{q}{E_{h}+E_{p}}
$$

ここで、COP $\operatorname{COP}_{p}: 1$ 次側 COP[-]、q : 熱源生産熱流量 $[\mathrm{kW}] 、 E_{h}$ ： 熱源消費電力 $\left[\mathrm{kW} 、 E_{p}: 1\right.$ 次ポンプ消費電力 $[\mathrm{kW}]$

\section{（2）実測結果}

図8から図10、表9に実測結果を示す。なお、16日の17時から 22 時は運用の切り替えを行ったため、検討データから除外した。

〈外界気象・2陼室温〉 (図8)

case $\alpha-2$ 実施時の方が、 case $\alpha-1$ 実施時に比べ全体的に外気温度 が低かった。18日の午前中には雨が降っていたため、相対湿度が $100 \%$ 近くになっている時間帯が見られる。両ケースとも、空調時間 帯において室温はほぼ設定温度に制御されている。

〈熱源冷水出入口温度 - 流量 - 生産熱流量〉(図9)

case $\alpha$-1と比べcase $\alpha$-2では、熱源インバータ制御により熱源生 産熱流量が減少している。同様に1次ポンプもインバータ制御され

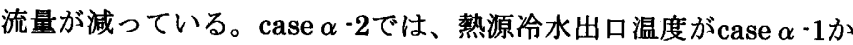
ら約 $2 \mathrm{~K}$ 上昇し概ね $7^{\circ} \mathrm{C}$ となっている。17日の6時頃に熱源冷水出口 温度が $5^{\circ} \mathrm{C}$ 近くになっているのは、蓄熱完了が近づくにつれ蓄熱槽 の高温側が低温になり、三方弁による温度制御が働かなくなったた めである。

\section{〈蓄熱目標・蓄熱量・熱源生産熱流量〉(図10)}

case $\alpha-1$ では全負荷運転で前詰めに蓄熱が行われ、5時前後に蓄熱 が完了しているが、 case $\alpha$-2では8時前後まで部分負荷運転による蓄 熱が行われている。

\section{〈日積算平均値 ・ COP〉 (表9)}

熱源生産熱量、空調機除去熱量、電力消費量について、両ケース それぞれの日積算平均値を求め、熱源COP、1 次側COPを算出した。 但し、算出にあたり、蓄熱開始からの積算値を比較するため、前日 22時からを1日として計算した。case $\alpha$-1と比べ、case $\alpha$-2では熱源

表 8 ケース設定 (著熱空調システム)

\begin{tabular}{c|c|c}
\hline & case $\alpha \cdot 1$ & case $\alpha-2$ \\
\hline 熱源機器 & 全負荷運転 & インバータ制御最高効率点で運転 \\
\hline 1 次ポンプ & 全負荷運転 & インバータ制御最高効率点で運転 \\
\hline 三方弁熱源出口温度 & $5.1^{\circ} \mathrm{C}$ & $7.1^{\circ} \mathrm{C}$ \\
\hline 蓄熱基準温度 & $6.0^{\circ} \mathrm{C}$ & $8.0^{\circ} \mathrm{C}$ \\
\hline 熱交換器 2 次側送水温度 & $7.0^{\circ} \mathrm{C}$ & $9.0^{\circ} \mathrm{C}$ \\
\hline 熱交換器 2 次側僈水温度 & $14.0^{\circ} \mathrm{C}$ & $16.0^{\circ} \mathrm{C}$ \\
\hline
\end{tabular}

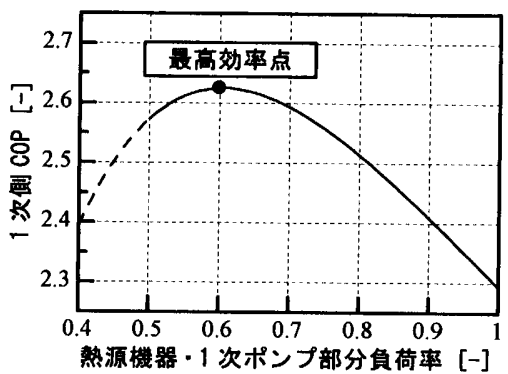

図 7 部分負荷率と 1 次側 COP の関係

表 9 日積算平均値・ COP (蓄熱空調システム)

\begin{tabular}{c|r|r}
\hline & case $\alpha \cdot 1$ & case $\alpha \cdot 2$ \\
\hline 空調機除去熱量[kWh] & 462.2 & 324.2 \\
\hline 熱源生産熱量[kWh] & 522.5 & 370.1 \\
\hline 熱源電力消費量 $[\mathrm{kWh]}$ & 161.0 & 90.5 \\
\hline 1 次ポンプ電力消費量[kWh] & 15.4 & 6.1 \\
\hline 空調機電力消費量合計[kWh] & 115.8 & 120.1 \\
\hline システム電力消費量 $[\mathrm{kWh]}$ & 311.9 & 236.8 \\
\hline 熱源 COP $[\cdot]$ & 3.25 & 4.09 \\
\hline 1 次側 COP $[-]$ & 2.96 & 3.83 \\
\hline システム COP $[\cdot]$ & 1.48 & 1.37 \\
\hline
\end{tabular}


COPが3.25から4.09に向上し、1 次側COPは2.96 から3.83に向上 した。熱源機器の効率は外気温度に左右されるが、熱源機器が稼動

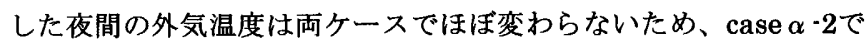
の省エネルギー効果は顕著である。ファンの電力消費量は除去熱量 の大小に係わらずほぼ一定となるため、外気条件の違う両者のシス テムCOPを比較することはできないが、2次側の運用は変更してい ないので、システム全体を考えても熱源機器と 1 次ポンプの電力消 費量の削减分は省エネルギーが図られていると考えられる注2。

\section{3 非蓄熱空調システムにおける実測調査}

\section{(1) 実測概要}

非蓄熱空調システムの実測でも蓄熱空調システムの実測と同様に、 従来の運用方法で運転を行う case $\beta$-1 熱源機器・1次ポンプでの効 率向上を図れるよう設定したcase $\beta$-2を実施した。2ケースの設定条 件を表10に示す。

〈case $\beta-1\rangle(21$ 日 0:00 22日 18:00)

従来から対象空調システムにおいて行われている運用で、熱源機 器では熱源冷水入口温度に応じて圧縮機の運転台数を、4台-2台-0 台と切り替える圧縮機台数制御運転を行う。したがって、2次側の 還水の温度状態を熱源冷水入口温度センサーに反映させる必要があ る(図2(b))。そのため、1次ポンプは空調時間帯中であれば圧縮機の 運転台数にかかわらず常に全負荷運転を行う。

$\langle$ case $\beta-2\rangle(23$ 日 0:00 25日 24:00)

従来から熱源機器に対して行っている圧縮機台数制御に加えて、 インバータ制御を行う。非蓄熱空調システムでは負荷に応じた熱量 生産が必要なため、蓄熱空調システムで実施したような最高効率点

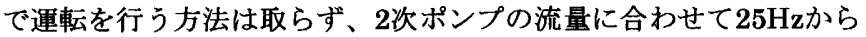
$50 \mathrm{~Hz}$ の間で熱源機器のインバータ周波数を変化させる運転を赛施 した。2次ポンプの流量と周波数の関係を図11に示す。2次ポンプは インバー夕制御により、空調機の処理熱量に応じて流量を変化させ るため、熱源機器も負荷に匛じて運転されることになる。1次ポン プも2次ポンプの流量に応じて $30 \mathrm{~Hz}$ から $50 \mathrm{~Hz}$ の間でインバータ制 御され、流量を変化させる(図11)。1次ポンプの最低周波数を熱源機 器よりも高くしたのは、熱源冷水出口温度の低下を避けるためであ る。1次ポンプと熱源機器では、周波数に対する部分負荷率の関係 が異なるため、1次ポンプと熱源機器を同周波数で運転すると、低 周波数域で熱源機器の熱流量が1次ポンプの流量に対して大きくな る。そのため、熱源冷水出口温度が低下する。熱源冷水出口温度が

表 10 ケース設定 (非苗熱空調システム)

\begin{tabular}{|c|c|c|}
\hline & case $\beta \cdot 1$ & case $\beta \cdot 2$ \\
\hline 熱源機器 & 圧縮機台数制御 & $\begin{array}{c}\text { 圧縮機台数制御+2 次ポンプ流量に応じて } \\
25 \sim 50 \mathrm{~Hz} \text { の範讲でインバータ制御 }\end{array}$ \\
\hline 1 次ポンプ & 全負荷運転 & $\begin{array}{c}2 \text { 次ポンプ流量に応じて、30〜 } 50 \mathrm{~Hz} \\
\text { の範囲でイバータ制御 }\end{array}$ \\
\hline
\end{tabular}

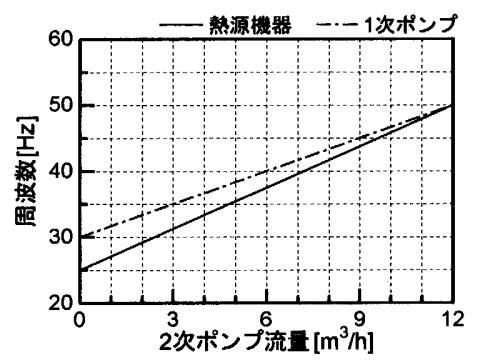

図 112 次ポンプ流量と周波数の関係

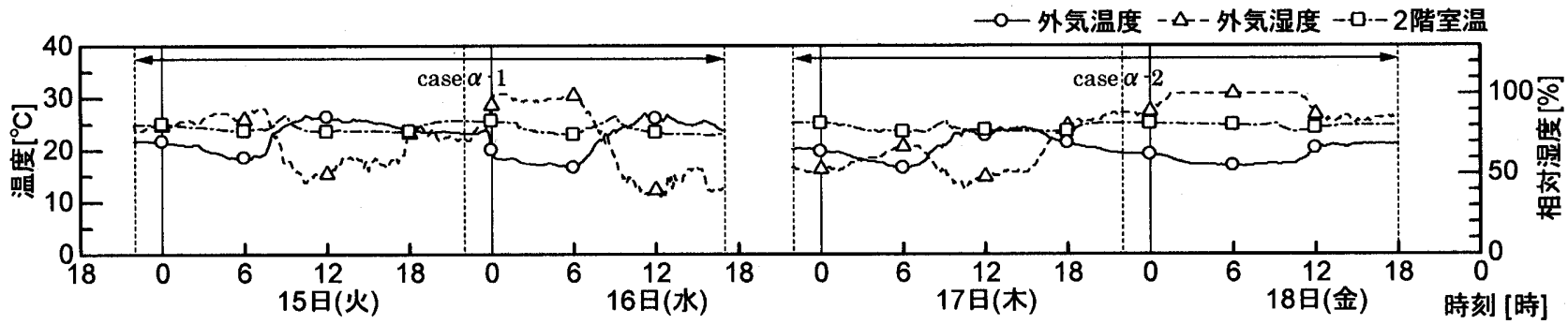

图 8 外界気象・2 階室温（蓄熱空調システム）

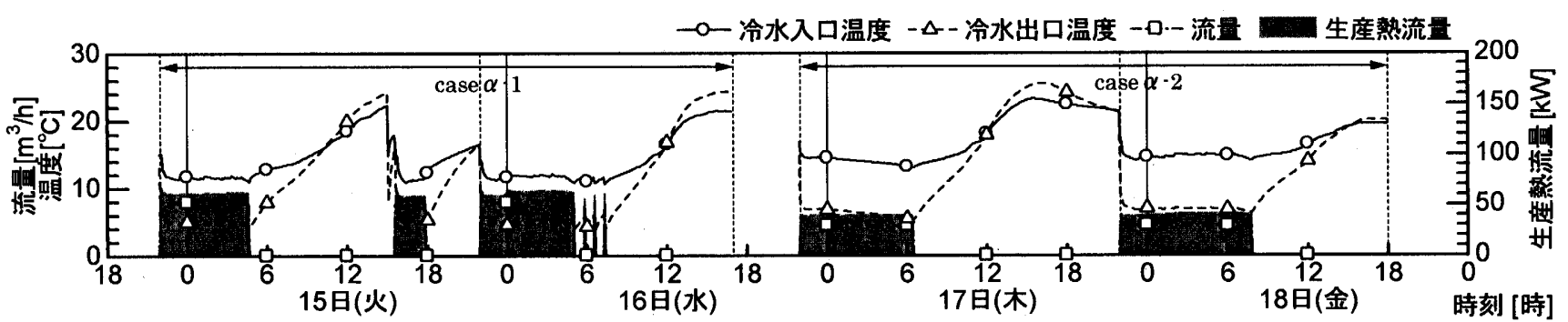

図 9 熱源冷水出入口温度・流量・生産熱流量（蓄熱空調システム）

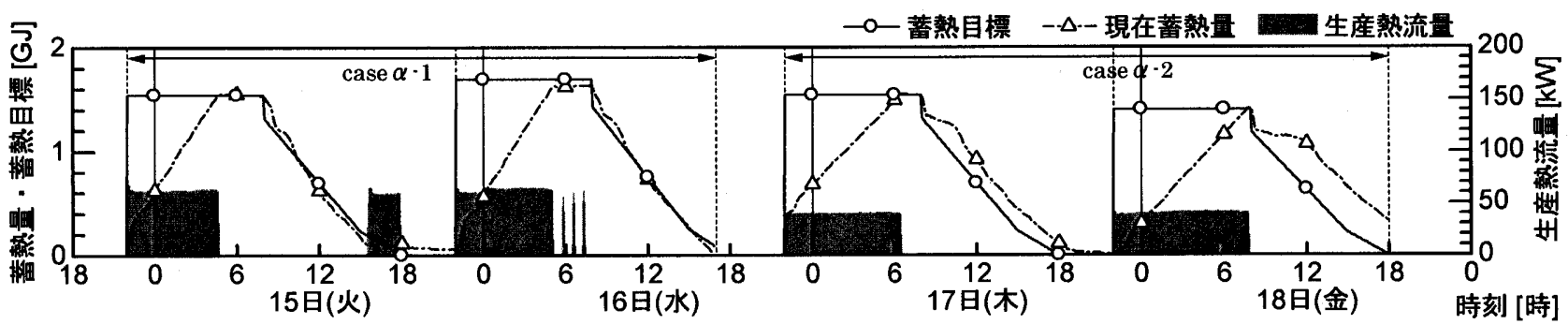

図 10 蓄熱目標・蓄熱量・熱源生産熱流量（蓄熱空調システム） 
$4.0^{\circ} \mathrm{C}$ を回ると、熱源機器は凍結防止のため停止する。

非蓄熱空調システムでも熱源椧水出口温度の上昇を図ることによ る熱源機器の効率向上が考えられるが、従来の設定值でも負荷が小 さい場合は既に熱源冷水出口温度が $9.0^{\circ} \mathrm{C}$ 以上になっており、これ以 上の温度上昇は空調時の除湿性能や冷房性能に影響を及ぼす可能性 がある。そのため、case $\beta$-2において熱源冷水出口温度の設定值を 上げることはあえて行っていない。

\section{(2) 実測結果}

図12、図13、表11に実測結果を示す。なお、22日の18時から 24 時は運用の切り替えを行ったため、検討データからは除外している。 〈外界気象・2階室温〉(図12)

蓄熱空調システムの実測時と比べて全体的に外気温度は低かった。 特に24日は外気温度が低く、日中を通して $15^{\circ} \mathrm{C}$ を超えることがほと んどなかった。実測期間中、空調時間帯において室温はほぼ設定温 度に制御されており、両者に大きな違いは見られなかった。

\section{〈熱源冷水出入口温度・流量 - 生産熱流量〉（図13）}

24日は外気温度が低く、空調負荷があまり発生しなかったため、 熱源機器はほとんど運転されなかった。他の日も空調負荷が小さく、 熱源機器では圧縮機台数制御や、熱源冷水出口温度が $4.0^{\circ} \mathrm{C}$ を回る ことによる停止が頻繁に行われていた。そのため、機器の発停に伴 う熱源冷水出入口温度の振動が、case $\beta-1$ 、 case $\beta-2$ とも見られた。 case $\beta$-2ではインバータ制御により、熱源生産熱流量が変化してい る。1次ポンプも熱源機器と連動してインバータ制御が行われてい るため、熱源生産熱流量と冷水流量の変化には同様の傾向が見られ、 熱源生産熱流量が小さいときには流量が削減されている。

〈日積算平均值 - COP > (表 11)

熱源生産熱量、空調機除去熱量、電力消費量について両ケースの 日積算平均值を求め、その值から熱源COP、1 次側COP、システム COPを算出した。但し、case $\beta$-2の平均值は 24 日に熱源機器がほと んど運転されなかったため、23日と 25 日の值を平均し算出した。 case $\beta$-1と比べ、case $\beta$-2では熱源COPが3.04から 3.54に向上し、1 次側COPは2.06から 2.98 に向上した。同一の気象条件下でないため 厳密には比較できないが、非蓄熱空調システムにおいてもcase $\beta$-2 により大きな省エネルギー効果が得られていると考えられる。case $\beta-1$ とcase $\beta$-2の間でシステムCOPに大きな差が見られないのは、 空調負荷が小さく、熱源生産熱量が小さかった今回の実測では、空 調機ファンの電力消費量がシステム電力消費量の70\%程度を占めて おり、1次側での省エネルギー効果が反映されにくいためである。

\section{4 シミュレーションによる熱源インバータ制御効果の検討}

実測調查では、蓄熱空調システム、非蓄熱空調システムそれぞれ に対して、熱源インバータ制御を含むいくつかの運用手法を実施し、 各システムにおいて十分な省エネルギー効果が得られることを明ら かにした。しかし、実測調查は中間季のごく短期間に実施しただけ であり、熱源インバータ制御の年間を通じた効果を把握する必要が ある。また、熱源インバータ制御は、負荷に応じて大きく効果が左 右される手法であるため、その効果は地域により格差が生じると予 想される。そこで空調システムシミュレーションを用いて、いくつ かの運用方法について年間の省エネルギー効果を把握するとともに、 気象条件の異なる日本国内6都市でどの程度の効果が得られるのか を明らかにした。

\section{1 計算概要}

計算対象に4階建ての事務所ビルを想定した。計算対象建物概要 を表12に、基淮階平面図を図14に、空調システム系統略図を図15に

表 11 日積算平均値・COP(非蓄熱空調システム)

\begin{tabular}{|c|c|c|}
\hline & case $\beta \cdot 1$ & case $\beta \cdot 2$ \\
\hline 空調機除去熱量[kWh] & 93.5 & 90.3 \\
\hline 熱源生産熟量[kWh] & 116.3 & 107.9 \\
\hline 熱源電力消費 $\mathrm{q}$ [ $[\mathrm{kWh}]$ & 38.2 & 30.5 \\
\hline 1 次ポンプ電力消費量[kWh] & 18.3 & 5.7 \\
\hline 空調機電力消费量合計 [kWh] & 117.1 & 125.5 \\
\hline システム電力消費量[kWh] & 181.8 & 170.4 \\
\hline 熱源 COP [-] & 3.04 & 3.54 \\
\hline 1 次側 COP [-] & 2.06 & 2.98 \\
\hline システム COP [-] & 0.51 & 0.53 \\
\hline
\end{tabular}

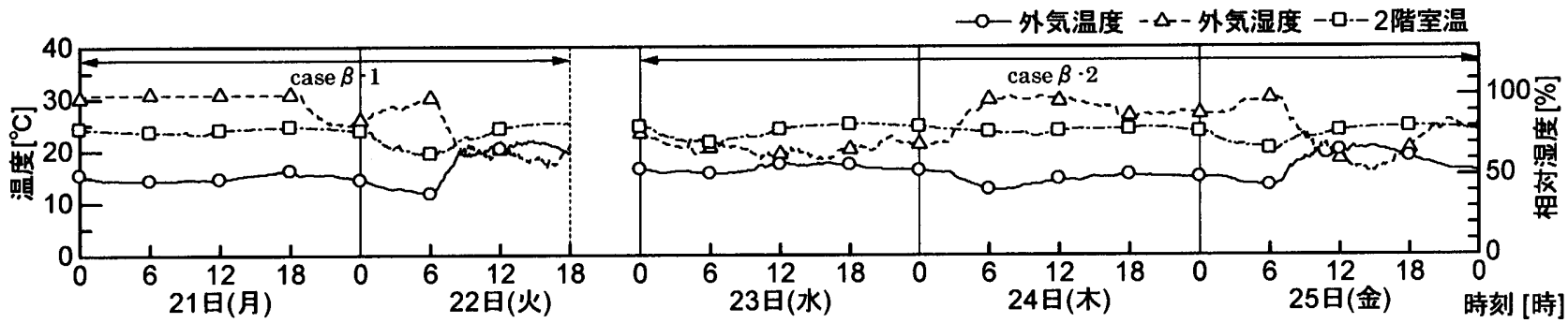

図 12 外界気象・2 階室温（非蓄熱空調システム）

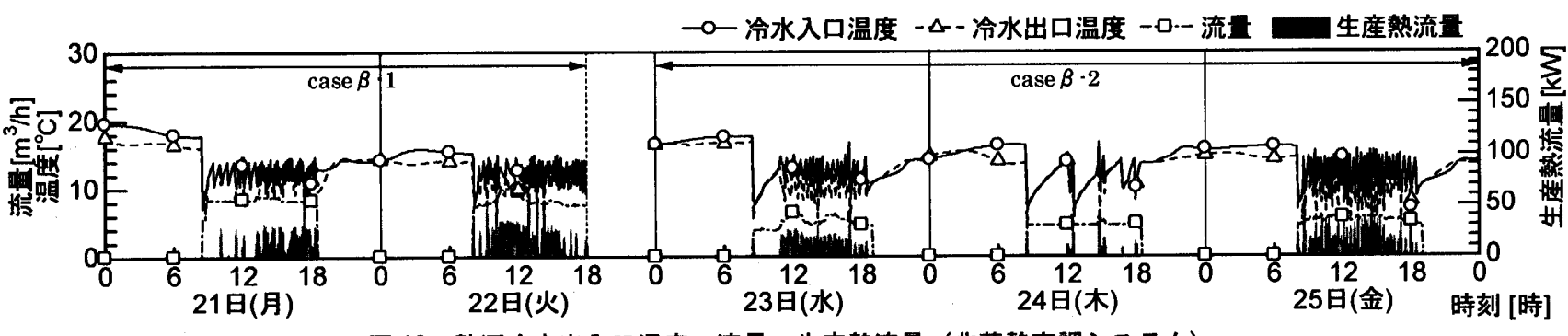

図 13 熱源冷水出入口温度・流量・生産熱流量（非蓄熱空調システム） 
示す。地域ごと、蓄熱空調システム・非蓄熱空調システムごとにシ ステムを構成する各機器を選定し、計算を行った。熱源機器のイン バー夕制御特性には実験により得られた值(表5、熱源機器A)を用い た。冷房時の能力比・入力比の算出には図5に示寸特性を使用し、暖 房時にも機器の仕様書より求めた暖房時の能力比・入力比を使用し た。建物熱負荷の計算には、HASP/ACLD 5)の計算時間間隔を1時間 から1分まで変更可能にしたものを用いた。計算時間間隔は1分であ る。空調時間帯は8:00〜19:00であり、土曜日、日曜日、祝日は運転 しない。

\section{2 年間エネルギー削減量に関する検討}

実測調查で行った運転方法を一年間続けた場合、どの程度の省エ ネルギー効果が得られるのか蓄熱空調システム、非蓄熱空調システ ムそれぞれで計算を行った。実測を行ったシステムのように熱源機 器もしくは圧縮機の台数制御による生産熱量の調整が、多くのシス テムで採用されている。こうしたシステムに熱源インバータ制御の 導入を考える場合、すべての機器にインバータを取り付けることは イニシャルコストの面で不利である。そこで、圧縮機の半数にのみ インバータを取り付けた場合の効果についても把握を行った。 $4 、 5$ 、 10、11月を中間期(冷房、設定室温 $24^{\circ} \mathrm{C}$ )、6月～9月を夏期(冷房、設 定室温 $26^{\circ} \mathrm{C}$ )、12月〜3月を冬期(暖房、設定室温 $22^{\circ} \mathrm{C}$ ) とした。

\subsection{1蓄熱空調システムにおける検討}

\section{(1) 検討ケ一ス}

〈case A-1〉実測調查を行った建物で従来行われていた運用方法を 適用したケースである。熱源機器、1次ポンプともに全負荷運転を 行う。

〈case A-2〉冷房時、暖房時とも最高効率点での運転を基本とする。 最高効率点での運転では蓄熱時間帯中の蓄熱完了が見込めない場合、 全負荷運転に切り替える。冷房時の最高効率点を図16に示す。なお、 暖房時には熱源インバータ制御の効果はほとんどないが、1次ポン プインバータ制御が有効なため、圧縮機4台のうち2台を全負荷運転 し、1次ポンプを部分負荷率0.5で運転した場合が最高効率点となる。 〈case A-3〉4台の圧縮機のうち2台はインバータ制御、残り2台は ON/OFF制御とし、できる限り最高効率点で運転を行う。この際、 冷房時の最高効率点は圧縮機 2 台をインバータ制御で部分負荷率 0.33とした点になるが、それでは出力が不足しやすいため、圧縮機 運転台数が 4 台の時に最も 1 次側 COPが高い点(高効率点 : 部分負荷 率0.81）でも運転することとした。冷房時の最高効率点、高効率点 を図16に示す。暖房時の最高効率点はcaseA-2 と同様である。

\section{（2）計算結果}

計算結果を表13、図17に示す。なお、日積算平均值は、蓄熱開始 時刻の22時から翌日22時までを1日として集計した。caseA-2では caseA-1と比べて、熱源機器電力消費量が夏期には約 $10 \%$ 、中間期 には約 $15 \%$ 削減された。そのため、システムCOPは夏期に約 $8 \%$ 、 中間期には約 7\%向上した。caseA-3でも、caseA-2 と同程度の十分 な省エネルギー効果が得られた。冬期のシステムCOPはどのケース もほぼ変わらなかった。年間では、caseA-1に比べcaseA-2 の電力 消費量は約6\%削减された。caseA-3でもほぼ同程度の効果が得られ ており、压縮機の半数のみにインバータを取り付けた場合でも十分 な効果が得られることが分かった。

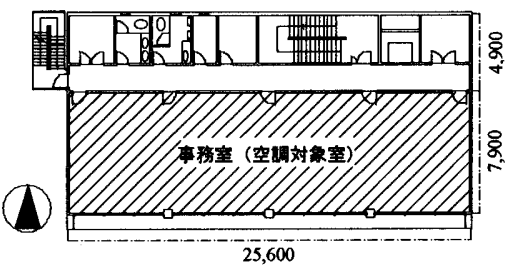

図 14 基準階平面図 (単位 : mm)

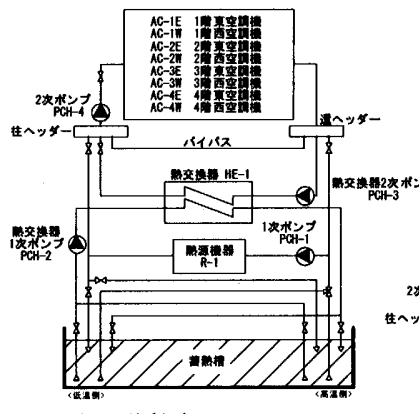

(a) 蓄熱空調システム
表 12 計算対象建物概要 主要用途 構造・階数 鉄骨造・地上4階 対象床面積 $808.96 \mathrm{~m}^{2}$ 対象室容積 $2588.67 \mathrm{~m}^{3}$

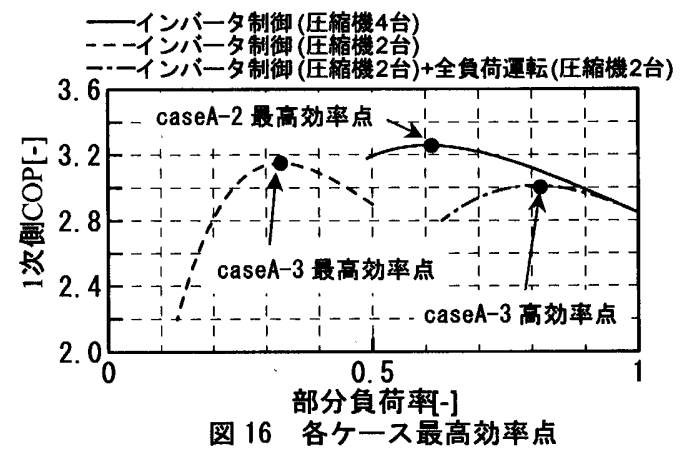

表 13 計算結果 (各期間日積算平均値 - COP)

\begin{tabular}{|c|c|c|c|c|c|c|c|c|c|c|c|c|c|c|c|c|c|c|c|}
\hline & \multirow{2}{*}{$\begin{array}{c}\text { 期間 } \\
\text { case }\end{array}$} & \multicolumn{3}{|c|}{ 夏期 } & \multicolumn{3}{|c|}{ 中間期 } & \multicolumn{3}{|c|}{ 冬期 } & \multicolumn{3}{|c|}{ 夏期 } & \multicolumn{3}{|c|}{ 中間期 } & \multicolumn{3}{|c|}{ 冬期 } \\
\hline & & $A-1$ & A-2 & $A-3$ & $A-1$ & $A \cdot 2$ & $A-3$ & $A-1$ & A-2 & A-3 & B-1 & B-2 & B-3 & B-1 & B-2 & B-3 & B-1 & B-2 & B-3 \\
\hline 空調機処理熱量合計 & [kWh] & 709.9 & 710.1 & 710.2 & 210.2 & 210.2 & 210.2 & 68.5 & 68.7 & 68.7 & 702.1 & 710.2 & 710.2 & 209.0 & 209.9 & 209.9 & 68.6 & 68.2 & 68.3 \\
\hline 熱源機器生産熱量 & [kWh] & 795.8 & 793.6 & 794.1 & 295.9 & 294.8 & 296.1 & 106.6 & 106.7 & 106.7 & 798.3 & 747.6 & 746.9 & 281.8 & 236.7 & 236.7 & 72.7 & 80.5 & 80.2 \\
\hline 熱源機器電力消費量 & {$[\mathrm{kWh}]$} & 213.1 & 192.1 & 192.6 & 62.3 & 53.3 & 53.7 & 33.2 & 33.3 & 33.3 & 220.9 & 176.0 & 190.7 & 64.5 & 47.8 & 47.9 & 23.2 & 26.6 & 26.6 \\
\hline 1 次ポソプ 電力消費量 & [kWh] & 16.3 & 14.1 & 14.9 & 5.8 & 4.2 & 5.3 & 2.1 & 1.7 & 1.7 & 40.7 & 9.9 & 10.1 & 40.7 & 9.4 & 9.4 & 40.7 & 9.5 & 9.6 \\
\hline 空調機電力消費量合計 & [kWh] & 51.7 & 51.7 & 51.7 & 46.4 & 46.4 & 46.4 & 52.9 & 52.9 & 52.9 & 58.9 & 51.6 & $\mathbf{5 1 . 7}$ & 48.1 & 46.4 & 46.4 & 53.0 & 53.1 & 53.1 \\
\hline 2 次側ポンプ電力消費量合計 & [kWh] & 50.6 & 50.4 & 49.3 & 39.4 & 39.4 & 39.1 & 16.2 & 16.3 & 16.3 & 22.2 & 20.3 & 19.9 & 13.4 & 12.2 & 12.2 & 4.8 & 4.7 & 4.7 \\
\hline 沃㳂電力消費量 & {$[\mathrm{kWh}]$} & 331.8 & 308.2 & 308.5 & 153.8 & 143.3 & 144.5 & 104.4 & 104.2 & 104.2 & 342.7 & 257.8 & 272.4 & 166.8 & 115.9 & 116.0 & 121.7 & 94.0 & 94.0 \\
\hline 熱源 COP & {$[-]$} & 3.73 & 4.13 & 4.12 & 4.75 & 5.53 & 5.51 & 3.21 & 3.20 & 3.20 & 3.61 & 4.25 & 3.92 & 4.37 & 4.95 & 4.94 & 3.14 & 3.02 & 3.01 \\
\hline 1 次側 COP & {$[-]$} & 3.47 & 3.85 & 3.83 & 4.35 & 5.13 & 5.02 & 3.02 & 3.05 & 3.05 & 3.05 & 4.02 & 3.72 & 2.68 & 4.13 & 4.13 & 1.14 & 2.23 & 2.22 \\
\hline システム COP & {$[-]$} & 2.14 & 2.30 & 2.30 & 1.37 & 1.47 & 1.46 & 0.66 & 0.66 & 0.66 & 2.05 & 2.75 & 2.61 & 1.25 & 1.81 & 1.81 & 0.56 & 0.73 & 0.73 \\
\hline
\end{tabular}




\subsection{2 非蕃熱空調システムにおける検討}

\section{(1) 検討ケース}

〈caseB-1〉実測調查を行った建物で従来行われていた運用方法を適 用したケースである。熱源機器では、熱源冷水入口温度に応じて圧 縮機の運転台数を 4 台- 2 台-0台と切り替える圧縮機台数制御運転を 行う。1次ポンプは空調時間帯中常に全負荷運転を行う。 〈caseB-2〉非蓄熱空調システムでは、熱源機器の運転は空調機の運 転状況に合わせて出力を調節する必要がある。そこで、各空調機の 負荷に応じて流量を変化させる2次ポンプの部分負荷率をもとに、 熱源機器、1次ポンプの部分負荷率を決定し、インバータ制御する。 〈caseB-3〉インバー夕を圧縮機の半数にのみ取り付けて運転を行う ケースである。caseB-2と同様、2次ポンプの部分負荷率をもとに熱 源機器、1次ポンプのインバータ出力を決定する。

(2) 計算結果

計算結果を表13、図18に示す。caseB-2ではcaseB-1と比べ、熱源 機器電力消費量が夏期には約 $20 \%$ 、中間期には約 $26 \%$ 削減された。 そのため、システムCOPは夏期に約 $34 \%$ 、中間期に約 $45 \%$ 向上した。 また、冬期には熱源機器電力消費量の削減は見られないが、システ ムCOPは約 $30 \%$ 向上した。この要因として1次ポンプでの電力消費 量削減が挙げられる。caseB-1のモデルとした実測調查を行った建 物で従来行われていた非蓄熱空調システムにおける運用では、2次 側の還水の温度状態に合わせて熱源機器を制御するため、空調時間 帯中であれば常に1次ポンプは全負荷運転を行っていた。そのため、 1次ポンプのインバータ制御による効果が大きく現れた。熱源機器 を全負荷運転とし、1次ポンプの部分負荷率を下げると熱源機器の 出入口温度差が大きくなりすぎるため、凍結等の危険がある。しか し、熱源インバータ制御により1次ポンプの部分負荷率に合わせて 熱源機器の部分負荷率を下げることで、こうした危険を回避できる。 そのため、熱源インバータ制御と1次ポンプインバータ制御の併用 は非常に効果的である。冷房時に両者間に熱源生産熱量の差が見ら れるが、これは1次ポンプの電力消費量削堿に伴い、発熱による熱 損失が减少したことによる。caseB-3でも熱源機器電力消費量が夏 期には約 $14 \%$ 、中間期には約 $26 \%$ 削減され、システムCOPは夏期に 約 $27 \%$ 、中間期に約 $28 \%$ 向上した。年間では、caseB-1からcaseB-2 で約 $26 \%$ の電力消費量削堿となった。caseB-3でも約 $24 \%$ の電力消費 量削堿が達成されており、非蓄熱空調システムにおいても圧縮機の 半数にインバータを取り付けた際に十分な効果が得られることが分 かった。

\section{3 各地域における熱源インバータ制御道入効果の試算}

前節で検討したような運用方法は、熱源機器や1次ポンプの部分 負荷率に応じて消費電力が決定されるため、その省エネルギー効果 はこれらの機器がどの程度の部分負荷率で運転されるかによって大 きな影響を受ける。そのため、気候の違いによって空調負荷の出現 パターンが異なればその効果も大きく異なると推測される。そこで、 気象条件の異なる日本国内6都市の気象データを用いて空調システ ムシミュレーションを行い、熱源機器と1次ポンプにインバータ制 御を導入した運用がどのような地域でより有効かを検討した。対象 都市は、札幌・仙台・東京・福岡・鹿览島・那两の6都市である。 図19に6都市の月平均気温の推移を示す。気象データには標準気象
データを、対象とする建物、空調システムのモデルは前節と同じも のを用いた。但し、熱源機器・ポンプ・空調機は都市ごとに最大負 荷計算を行って選定している。4〜11月に冷房運転、12３月に暖房 運転を基本としているが、寒冷な時期が長い札幌では暖房運転期間 が長く、温暖な時期が長い那覇では冷房運転期間が長くなるよう設 定している(図20)。

\section{3.1 蓄熱空調システムにおける検討}

前節で示した caseA-1 と caseA-2 の運転について計算し、比較を 行った。計算結果として各都市でのシステム電力消費量を図 21 に示 す。図には caseA-1 を基準とした caseA-2 における電力消費量の削 减率を併記している。それぞれが日本の代表的な気候である 6 都市 すべてにおいて、caseA-2 では電力消費量が削減されている。この
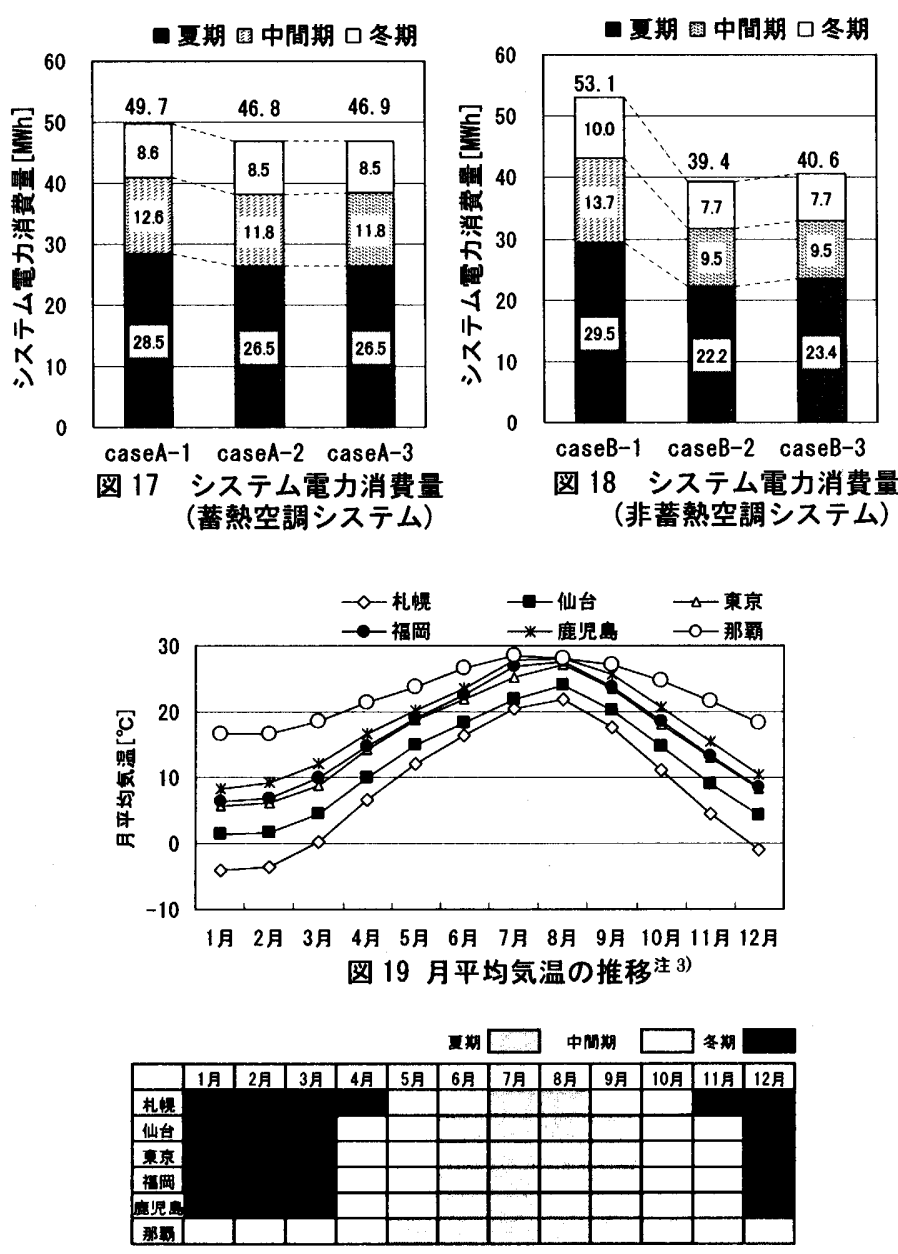

図 20 年間空調スケジュール

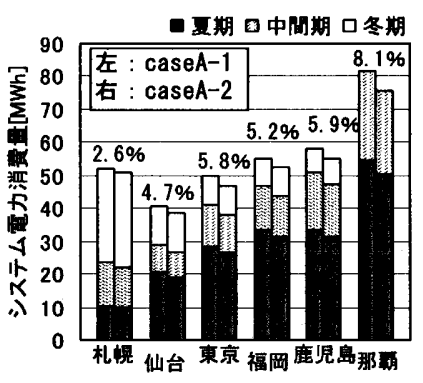

図 21 システム電力消費量 (蓄熱空調システム)

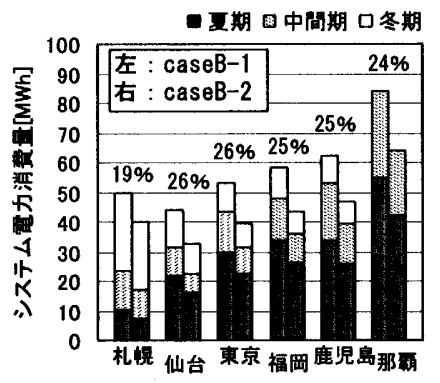

図 22 システム電力消費量

（非蓄熱空調システム） 
ことから日本国内のほとんどの地域で熱源機器、1次ポンプにイン バー夕を導入する効果は得られると推測される。最も効果が大きか ったのは那羁で、8.1\%の省エネルギー効果が得られた。逆に効果が 小さかったのは札幌で $2.6 \%$ の省エネルギー効果であった。暖房時に 比べ冷房時に熱源インバータ制御の効果が大きいため、このような 結果になったと推測される。

\section{3.2 非蓄熱空調システムにおける検討}

前節で示したcaseB-1 と caseB-2の運転を対象都市で実施した場 合、どの程度電力消費量に差があるのか計算を行った。計算結果と して各都市でのシステム電力消費量を図22に示す。各地域において 夏期、中間期、冬期とも電力消費量の削減が見られるが、特に夏期 において削减量が大きい。電力消費量の削減率は最も低い札幌でも $19 \%$ 、最も高い仙台では $26 \%$ と各都市で年間を通じて高い削减率と なっており、非蓄熱空調システムに熱源インバータ制御、1次ポン プインバータ制御を導入することは、地域によらず大きな効果が期 待できる。

\section{5 おわりに}

本報で得られた知見を以下にまとめる。

(1) 熱源インバータ制御特性把握実験では、汎用の熱源機器の圧縮 機部分にインバータを取り付け、インバータ制御時の部分負荷 特性を測定した。その結果、冷房運転時には全負荷運転よりも 高効率な部分負荷運転が可能であることが分かった。また、イ ンバータ特性には圧縮機の仕組み等の差異による個体差がある ことが明らかになった。暖房運転時にはインバータ制御の効果 はほとんど見られなかった。その要因として暖房運転時には冷 房運転時に比べ熱損失が大きくなること、低部分負荷時におけ る機器発熱の減少が暖房時にはマイナスに作用すること等が考 えられる。

（2）熱源インバータ制御を用いた実測調查では、短期間ではあるが 実際のシステムに熱源インバー夕制御、1次ポンプインバータ制 御を用いた運用方策を導入することで、熱源COP・1 次側 COP の向上が顕著に見られた。

（3）シミュレーションによる検討では、熱源インバータ制御を用い た運用方策の年間を通した省エネルギー効果を把握した。その 結果、蓄熱空調システムで約6\%の省エネルギーを実現できた。 非蓄熱空調システムでは、その効果は大きく約 $26 \%$ の省エネル ギーとなった。また、熱源機器の半数にのみインバータを取り 付けて運用した場合でも、すべての熱源機器にインバータを取 り付けた場合と遜色ない省エネルギー効果が得られることがわ かった。

（4）熱源インバータ制御の導入効果を札幌、仙台、東京、福岡、鹿 児島、那羁を対象に計算したところ蓄熱空調システムでは、札 愰での省エネルギー効果が $2.6 \%$ で最も低く、那羁での省エネル ギー効果が $8.1 \%$ で最も高かった。その他の都市では $5 \%$ 前後で あった。非蓄熱空調システムでは、省エネルギー効果が最も低 かった札幌で $19 \%$ 、その他の都市では $25 \%$ 前後の高い省エネル ギー効果が得られる結果となった。
〈注〉

注1)実験では不具合なく運転できたが、圧縮機のみにインバータを取り付 けて行った実験であるため、ファンやその他の制御部が圧縮機の運転 状態に見合ったものになっていない可能性があり、この方法でインバ 一タを取り付ければ実用上問題がないというわけではない。 注2)今回の実測調查では熱源インバータ制御に加えて、熱源冷水出口温度 の上昇を図る設定を行ったため、熱源インバータ制御のみの省エネル ギー効果を明らかにすることはできていない。それについては4章で検 討を行った。熱源冷水出口温度の設定値を $2 \mathrm{~K}$ 上昇させた効果について は、シミュレーションによる試算で、中間期にシステム全体で約 $1 \%$ 省 エネルギーになるという結果を得ている。

注3) 1970 2000年の平均值。気象庁ホームページ(http://www.jma.go.jp/) より。

\section{〈参考文献〉}

1)山下周一他: 個別分散型空調システムのエネルギーシミュレーション, 日 本建築学会 2003 年度大会 (東海) 学術講演梗概集D-2, pp.1025·1026, 2003.9

2)古田島雄太他：空調冷熱源システムの運転実態と最適化改善手法に関す る研究 (第 1 報)冷水往・返温度差の実態とシステムCOPに与える影蠁, 空気調和・衛生工学会学術講演会講演論文集, pp.273-276, 2003.9

3)三菱電機株式会社編：インバータ応用マニュアル,電気書院 ,1985.4 4)電気書院編集部編：汎用インバータ活用ガイドブック,電気畫院，1985.4 5)松尾陽,横山浩一,石野久彌,川元昭吾 : 空調設備の動的熱負荷計算入門, 日 本空調衛生設備士協会, 1980.3

（2004年10月 7 日原稿受理， 2005 年 6 月 2 日採用決定） 